NEWS

\section{Oil cost hits ship studies}

Many of the research projects launched as part of the International Polar Year (IPY), which runs from March 2007 to March 2009, are under threat because of the steep rise in marine-fuel costs. Hundreds of Arctic and Antarctic scientists face uncertainty as polar science programmes worldwide are curtailed, postponed or cancelled.

The price of a barrel of oil has more than doubled since March 2007, from US\$60 to $\$ 140$ now. High energy costs are a problem for research in most fields, but logistically complicated research operations in remote polar regions are more affected than, say, big physics experiments.

"We have reached a point where the collapse of some of our activities is looming on the horizon," says Karin Lochte, director of the Alfred Wegener Institute for Polar and Marine Research (AWI) in Bremerhaven, Germany, which operates the research icebreaker Polarstern, Europe's largest scientific vessel.

Icebreakers are usually fuelled by marine diesel oil (MDO), a cleaner and more expensive fuel than the heavy oil used by normal cargo ships. The average price for MDO has increased fivefold since 2003 , from $\$ 250$ to $\$ 1,300$ per metric tonne (equivalent to around 1,200 litres of diesel). Since January, the price has increased by almost $\$ 550$ per tonne (see graph).

Operating the Polarstern, which is usually at sea for around 320 days per year, currently costs around $\$ 100,000$ per day, with fuel now accounting for half of that cost. Logistics experts at the AWI estimate that by the end of the year the institute will have exceeded, by more than $\$ 5$ million, its $\$ 30$-million budget for operating the ship. The German science ministry, from which the AWI receives $90 \%$ of its budget, has rejected requests to cover the extra costs.

"If fuel prices remain as high, we will be forced to cut projects and substantially reduce days at sea," says Lochte. One option, she says, is to cancel the Polarstern's entire Arctic programme next year. The ship could also be temporarily chartered to nonscientific users, she says.

More than 100 Polarstern scientists could be hit by cutbacks. Arctic projects at risk include a wide variety of geophysical, oceanographic and biological research, such as sampletaking in the AWI's Hausgarten, a deep-sea long-term observatory in the eastern Fram Strait, between Greenland and Spitsbergen, and

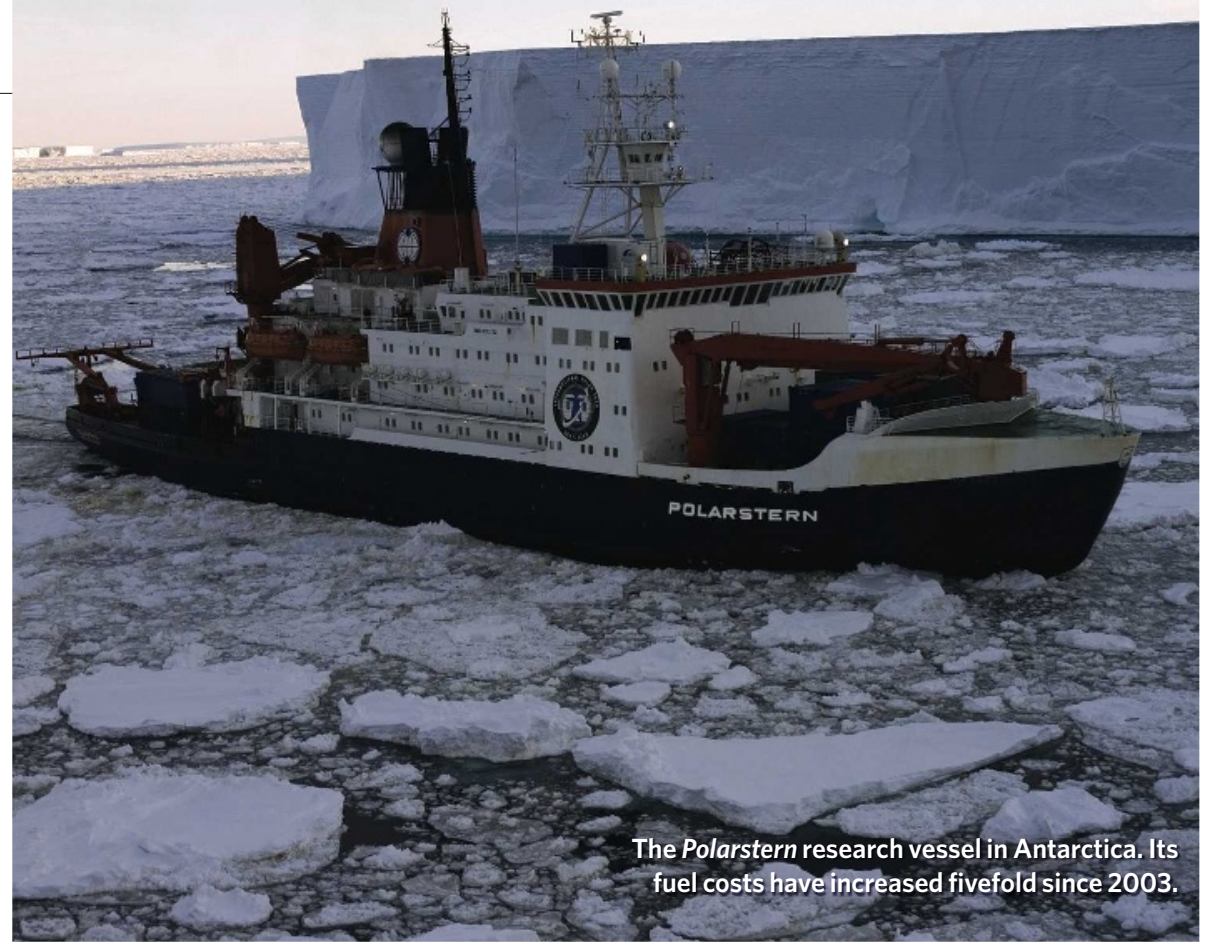

measurements of water flux through the strait.

Rising fuel costs threaten researchers from all countries involved in polar research. David Barber, chief scientist of the \$40-million Canadian-led Circumpolar Flaw Lead study — the biggest single IPY project - fears that such expensive expeditions might soon become unaffordable.

In the United States, increased fuel and transportation costs have caused a \$30-million shortfall in this fiscal year's \$350-million Antarctica budget of the National Science Foundation's Office of Polar Programs (OPP). The agency has asked the government for a budget increase to compensate for the extra costs. But Congress is unlikely to pass the request before the next US administration is in office.

"We have to figure out how to get through," says Karl Erb, director of the OPP. "We will make every effort to keep the science going and not cancel projects, but I do know we have to reduce or defer some of the things we had planned next year."

The OPP is operating four icebreakers and a fleet of cargo aircraft in support of Antarctic research activities. Although ship operations will

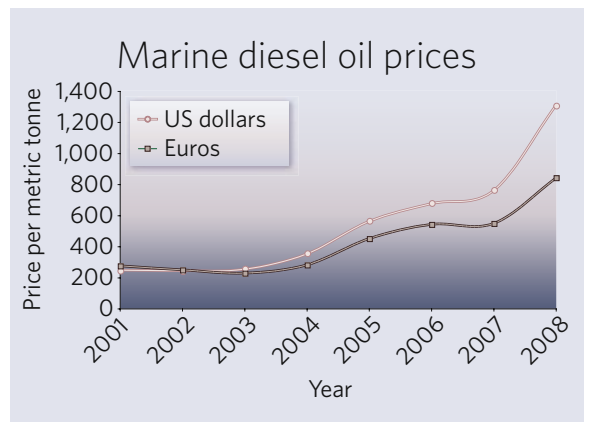

be maintained, the number of transport flights from New Zealand to Antarctica will be reduced, Erb says. A geophysical study of the Gamburtsev Mountains in eastern Antarctica - a large international IPY collaboration - is one of the projects that might get less air support, he says.

And the deployment of seismic sensors for the Polar Earth Observing Network (POLENET) project, an IPY collaboration with aims such as measuring the uplift of Earth's crust as a result of the West Antarctic ice sheet losing mass, may have to wait another year, says Erb.

Severe concerns about soaring costs were also raised last week in Moscow during the biennial meeting of the Scientific Committee on Antarctic Research (SCAR). "The common tenor is that painful cuts are unavoidable," says Lochte, the German delegate to SCAR. To mitigate the fallout, the group is now discussing saving money by improving international cooperation. Joint logistics would help to reduce the number of aircraft flights and ship operations required for supplying and maintaining Antarctic stations.

Reduced ship time could also be partly compensated for by a more widespread use of buoys, autonomous underwater vehicles and unmanned aircraft, says Lochte.

Alternatives to diesel-fuelled ship engines, perhaps on the basis of hydrogen-powered fuel cells, are in an experimental stage of development at best. Nuclear-driven research ships, such as the fleet of nuclear icebreakers that Russia has in use, are also an option - but one that most governments consider environmentally and politically too risky.

Quirin Schiermeier 